Supplement of Solid Earth, 6, 903-928, 2015

http://www.solid-earth.net/6/903/2015/

doi:10.5194/se-6-903-2015-supplement

(C) Author(s) 2015. CC Attribution 3.0 License.

Solid Earth

(c) (1)

Supplement of

\title{
A Web-based spatial decision supporting system for land management and soil conservation
}

\section{F. Terribile et al.}

Correspondence to: F. Terribile (fabio.terribile@unina.it)

The copyright of individual parts of the supplement might differ from the CC-BY 3.0 licence. 


\section{Supplementary material}

2

3

4

5

6

7

8

9

10

11

12

13

14

15

16

17

18

19

20

21

22

23

24

25

26

27

28

29

30

31

32

33

34

35

36

37

38

39

40

COMPLEMENTARY INFORMATION ABOUT THE OLIVE GROWING TOOL

Further information about the background

It has been said that olive tree cultivation in Valle Telesina has a very long tradition and that in last decades it has been overwhelmed by vineyards. In fact in last decades vineyard cultivation has shown to be a much better business than olive growing. This is inducing a sort of monoculture which is not good for ACP policy and the Agricultural Compliance system (Reg. EU 1303/2013; 1782/03) that focuses on biodiversity and soil conservation achieving more resilient agriculture systems. Moreover, olive grove farmers are seeking support in their effort to obtain a proper designation of origin labels for their olive oil.

Further information about main issues and main stakeholders of olive growing Below we report the main agriculture issues (named A hereafter) related to olive grove in Valle Telesina. Issue A1: In this situation public authorities are trying to stimulate alternative land uses with respect to vineyards by providing a specific Decree (D.M. 350/99) produced by the Italian Agriculture Ministry to preserve high quality oil (Olio extravergine di Oliva Sannio Caudino Telesino; further info at http://www.agricoltura.regione.campania.it/Tipici/prodotti tradizionali.htm). This relates to the production sites in Valle Telesina. This Decree of 1999 has not produced the desired results in terms of an increase in olive growth cultivation. The local region (Regione Campania) is therefore exploring alternative ways to promote olive growing in the Valle Telesina.

The main stakeholders and communities affected by issue A1 are: (a) the Agriculture Department of Regione Campania who has the problem to implement measures of the Rural Development Plan (on the basis of the ACP) with respect to olive tree cultivation, (b) olive grove farmers who have to promote their production and (c) local associations of olive oil producers (olive oil mills) who have to promote and market the importance of their olive oil.

Issue A2: Another difficulty for olive grove cultivation in Valle Telesina is the evidence that local farmers have very little technical assistance to proper planning (e.g. choice of varieties) and management during the growing season of their olive growing sites. Moreover, olive growing is so far a rather low-income business and involving private consultants is therefore not an attainable option.

The main stakeholders affected by issue A2 are not only farmers who require technical help but also the technical assistance office (named SESIRCA) of the Agriculture Department of Regione Campania. In fact, due to sever budget cuts, SESIRCA is not anymore in the position to provide the required technical assistance to olive growing farmers following the traditional extension procedures. Introduction of innovative, information-based computer systems might well allow rejuvenation of their role in future.

Further information about implemented SOILCONSWEB solution The SOILCONSWEB CGI system has been designed to support decision making towards both issues A1 and A2. A scheme of its main functionalities is reported in fig. SM15 which illustrates the hierarchical structure of the Olive growing tool; this includes many sub-tools in order to allow the end-user to deal with issues A1 and A2. They are (i) "Internet GIS" facilities (allowing to use GIS procedures without having a GIS desktop software), (ii) "Go and discover your landscape" (this produces a general overview of physical parameters of the AOI), (iii) 
"Label of your olive grove" (this enables the user to obtain an environmental and bioclimatic label of the AOI; (iv) "Support to the knowledge of your olive grove farm" (which can obtain mapping support) (e.g. olive tree varieties) for olive grove planning and (v) "Support to the management of your olive grove farm" (to assist in olive grove management).

In table SM1 details are given examples about addressed problems/employed tools/outputs for each category of end-user.

For instance end-users A1.1 - in order to design RDP measures (where/how/ to whom propose EU subsidies) for olive grove farmers - require operational Internet GIS tool (most local regional offices dealing with RDP do not have access to desktop GIS software) using official databases. In this way they can access olive grove suitability maps, bioclimatic indexes, soil maps for evaluating whether a specific territory is suitable to receive EU subsidy for olive growing.

End-user A1.2 are looking for "new ways" to help the marketing of their high quality olive grove-oil productions. Similarly to what happen to wine they were looking for "ways" to associate their olive oil production with a specific terroir in order to communicate to the consumer this association. Currently in Valle Telesina there are over $\mathbf{3 1 9 0}$ ha of olive grove with few hundreds olive farmers, then it was required to find a general operational solution to support any farmer/olive mill to better market their olives/oil. Then in SOILCONSWEB-CGI it was developed the tool "label of your olive grove" where the farmer can select (using a PC mouse) his farm and in real time it can obtain an environmental label (soil, geology, climate, last rain etc.) of his olive grove.

End-user A2.1 and A2.2 refer to farmers who - in absence of a public technical consultancy - aim to use the system to support their choice about selected technicalities such as choice of most suitable olive varieties and/or data about farm management (trend in rain, temperature, etc.)

End-user A2.3 are public body who is interested in evaluating the use of the system to populate the Regional Bulletin (Bollettino Fitosanitario Regione Campania) with an olive fly potential disease index (strongly connected to temperature gradient).

It is rather evident that each of the above applications for end-users would indeed require a very detailed description (and possibly an entire paper).

\section{COMPLEMENTARY INFORMATION ABOUT THE GROUNDWATER PROTECTION TOOL}

Further information about the background

It has been said about the many EU (and national) regulations aiming to protect groundwater from pollution (Nitrates Directive (Dir. 91/676), Water Framework Directive (Dir.60/00), Soil Thematic Strategy (COM 2006/231), Groundwater against pollution Directive (Dir. 80/68), Sewage sludge Directive (Dir. 86/276), Compliance System in Agriculture (Reg. (EC) 1782/031783/05ACP) and the evidence that there are still many problems in achieving an amelioration of groundwater pollution (e.g. COM2015/120; COM2013/683). Here we aim to stress that a key problem relies on the evidence that the full implementation of many directives about water quality/quantity in turn requires for a full competence (and managing capability) about the landscape, its multi-functionality, its dynamic nature (many processes, including fate of pollutants, are dynamic), required actions at local scale (many processes are site specific): in a single word, the main difficulty 
is coping with the inherent complexity of soils and landscapes. Most current approaches are not challenging this complexity, offering a simplistic, spatially aggregated and fragmented view of the problem. Moving towards local scale, in such complex scenario also Regione Campania administration is very much affected (e.g. infringement procedures by European Commission) and then it is looking for a better implementation of the above European directives.

Further information about main issues and main stakeholders of groundwater protection The main environmental issues (named E) dealing with the groundwater topic in Valle Telesina are given below. Issue E1: For implementing Water Framework Directive and Nitrate Directives, the Campania Region (as other European administrative regions) has the obligation to regularly update Nitrate Vulnerable Zones (in Italian named as ZVN) where Action Plans have to be applied to fulfill the required reduction in nitrate leaching towards groundwater. Then Campania Region is looking for procedures aiming to ameliorate ZVN delineation also in perspective of other pollutants. In terms of soil information, current delineation are based on empirical rules (only based on soil texture and soil organic matter content) of benchmark soils.

Issue E2: For the same reason of issue E1, Campania Region is looking for procedure to update and ameliorate the Action Plans for nitrate (formally regulated by DGR 209/2007). Current Action Plans are based on empirical rules of good agronomic practices.

Issue E3: Campania Region consider very important the critical issues of agronomic use of sewage sludge distribution and protection of water against pollution by nitrates from agricultural sources protection (regulated by DRD n. 160 of 22.04.2013 published in the Official Bulletin of Campania Region n. 22 of 29 April 2013; Technical Appendix at http://www.agricoltura.regione.campania.it/reflui/pdf/DRD 160-22-04-13.pdf). Here the criteria for the derogation from the prohibition of spreading time (typically occurring between $1^{\text {st }}$ December to middle February) are based on a special regional bulletin that takes into account rainfall and types of soils. Campania Region is evaluating whether is feasible to update and ameliorate the technical procedures employed in this bulletin. This entire issue is a rather hot topic in both policy and agriculture (in Italy and in many EU countries) because farmers have to stock very large amount of sewage in their farms independently by actual soil conditions.

Issue E4: Starting from this year, the Agriculture European Compliance System obliges farmers seeking financial support by EU to deliver also in terms of water and nitrate directives. In such framework, farmers require support in their land management to access EU aids.

The main bodies interested by issue E1, E2 and E3 is the Campania Region who is in charge of the implementation of the above regulations while $\mathrm{E} 4$ is an issue for farmers.

Further information about implemented SOILCONSWEB solution The SOILCONSWEB CGI system has been designed to support decision-making in contributing towards issues $1,2,3,4$. A scheme of its main functionalities is reported in fig. SM1 which illustrates the hierarchical structure of the tool; this includes some sub-tools. They are "Internet GIS" facilities which enable the use of GIS procedures without having a GIS desktop software, "Intrinsic Soil Protective Capability" which refer to a potential estimates of the intrinsic soil capacity to protect groundwater from pollution calculated on a set of climatic years (climate for 30 years from 1961 to 1990 taken as reference, Basile \& Terribile, 2008; Manna et al. 2009) and eventually the "Interactive Estimate of Soil Protection Capacity" here an opportunity is given to the user in 
1 order to evaluate the current protection capability by using current climate data and selecting the crop of

2 interest in the selected $\mathrm{AOI}$.

3 In table SM1 details are given about addressed problem/employed tools/outputs for each category of end-

4 user.

5 For instance end-users E1 - in order to update Vulnerable Zones (to be proposed to the Ministry of

6 Environment and EU Commission DG-ENV) - can use - for the Valle Telesina territory - both the operational

7 Internet GIS tool but most importantly the tool of "Potential protective capability towards groundwater

8 pollution" to estimate (with the support of modelling) potential vulnerable zones.

9 End-users E2 in order to update/ameliorate Action Plans (to be proposed to the Ministry of Environment and

10 EU Commission DG-ENV) - can use - for the Valle Telesina territory - the tool of "Actual protective capability towards groundwater pollution" to estimate whether a specific soil-crop combination maybe more/less protective in terms of limiting pollutant leaching towards groundwater. This information can then be incorporated into guidelines of Action Plans. End-users E3.1 have the very difficult role of establishing criteria for the derogation from the prohibition of sewage sludge distribution to soil. They can use both the tool "Actual protective capability towards groundwater pollution" and "Estimate current soil water content" to evaluate whether to include this additional parameter in the above criteria then diminishing the dispute about the current empirical approach (http://www.agricoltura.regione.campania.it/reflui/pdf/DRD 160-22-04-13.pdf). End-users E3.2 are farmers (or farmer association) who have to apply (through local municipalities) to the Campania Region asking to obtain a derogation from the prohibition of sewage sludge distribution to soil typically applying in the period $1 \mathrm{sr}$ December- $15^{\text {th }}$ February of each year. This end-user can use the system to evaluate whether his farm (or sets of farms) have a current (at day scale) soil index of soil protection appropriate to apply for derogation (the law established that if rains occur during the formal application procedure, the derogation has to be considered not valid). This document can support the farm application. End-user E4 are farmers (or association supporting farmers) who are willing to get EU subsidies regarding greening measures incorporated (from year 2015) into the EU Compliance System. These end-user by producing - on their farm - queries using tool "Actual protective capability towards groundwater pollution" in case their soil is protective, can support (on a voluntary base) their application with the documentation obtained by the SOILCONSWEB GCl system. 


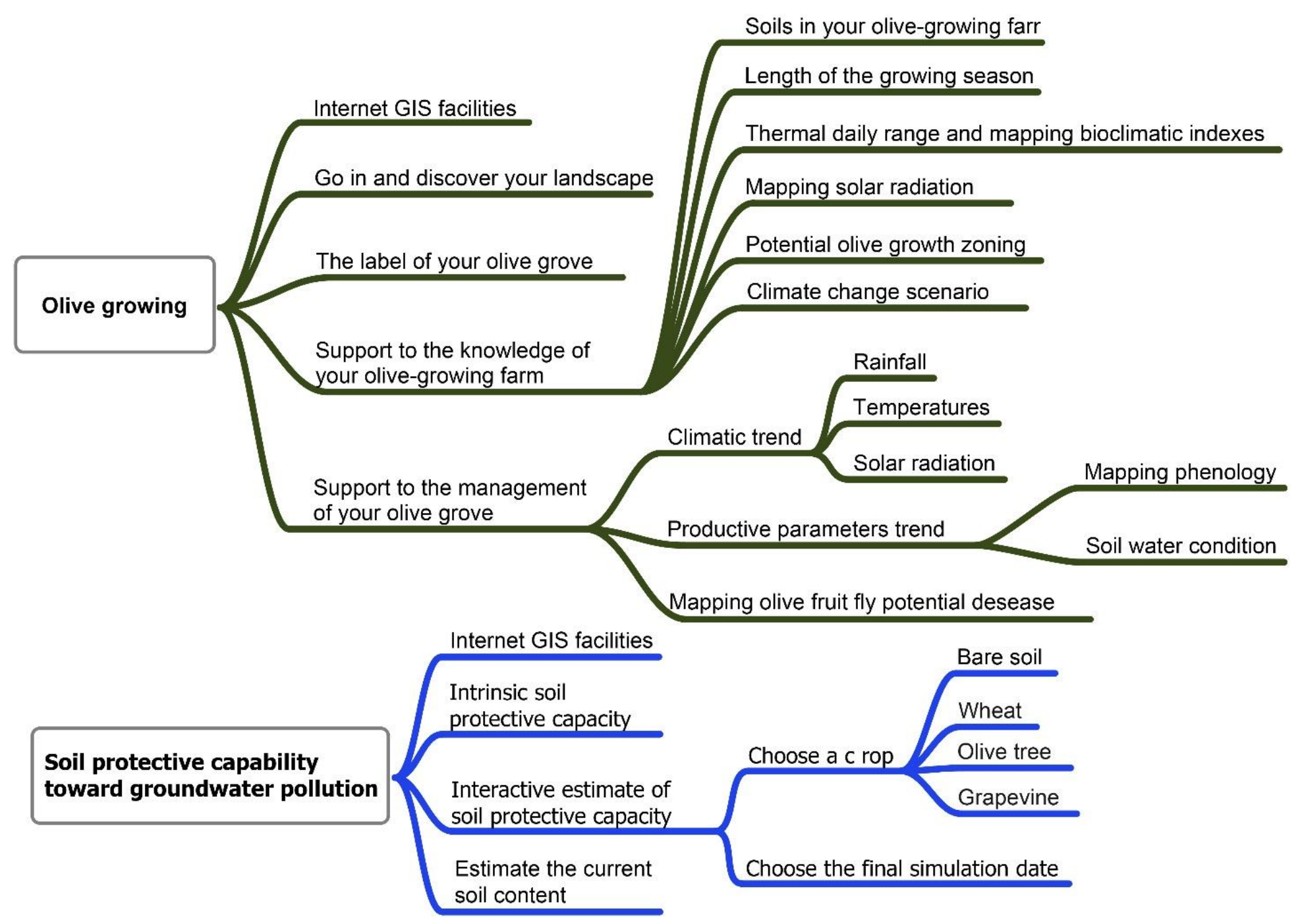




\section{Figure captions}

Fig. SM1 Supplementary material. Conceptual map illustrating the main themes of the Agriculture and Forestry dashboard; the Olive growing dashboard is presented as an example 


\begin{tabular}{|c|c|c|c|c|c|}
\hline Theme & Issue & $\begin{array}{l}\text { End-user } \\
\text { (stakeholders) }\end{array}$ & $\begin{array}{l}\text { Problem to } \\
\text { address }\end{array}$ & Employed tool & Output (example) \\
\hline \multirow{5}{*}{ 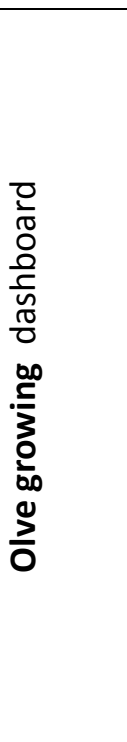 } & \multirow[b]{2}{*}{$\mathrm{A} 1$} & $\begin{array}{l}\text { A1.1.Agriculture } \\
\text { Department of } \\
\text { Regione Campania }\end{array}$ & $\begin{array}{l}\text { Design Rural } \\
\text { Development } \\
\text { Plan measures }\end{array}$ & $\begin{array}{l}\text { Internet GIS } \\
\text { facilities }\end{array}$ & $\begin{array}{l}\text { Maps (e.g. olive tree } \\
\text { suitability) to evaluate } \\
\text { impact of RDP measures, }\end{array}$ \\
\hline & & $\begin{array}{l}\text { A1.2 Olive growth } \\
\text { farmers and oil mill } \\
\text { associations }\end{array}$ & $\begin{array}{l}\text { Helping } \\
\text { marketing olive } \\
\text { oil using terroir } \\
\text { info }\end{array}$ & $\begin{array}{l}\text { Go and discover } \\
\text { your landscape } \\
\text { Label of your olive } \\
\text { grove }\end{array}$ & $\begin{array}{l}\text { Terroir info to be reported } \\
\text { in olive oil labels }\end{array}$ \\
\hline & \multirow{3}{*}{$\mathrm{A} 2$} & $\begin{array}{l}\text { A2.1 Olive growth } \\
\text { farmers }\end{array}$ & $\begin{array}{l}\text { Olive grove } \\
\text { planning }\end{array}$ & $\begin{array}{l}\text { Support to the } \\
\text { knowledge of } \\
\text { your olive grove } \\
\text { farm }\end{array}$ & $\begin{array}{l}\text { Climate and soil info to } \\
\text { choose olive varieties }\end{array}$ \\
\hline & & $\begin{array}{l}\text { A2.2.Olive growth } \\
\text { farmers }\end{array}$ & $\begin{array}{l}\text { Olive grove } \\
\text { management }\end{array}$ & $\begin{array}{l}\text { Support to the } \\
\text { management of } \\
\text { your olive grove } \\
\text { farm }\end{array}$ & $\begin{array}{l}\text { Trends in current climate } \\
\text { and production parameters }\end{array}$ \\
\hline & & $\begin{array}{l}\text { A2.3 SESIRCA - } \\
\text { Regione Campania }\end{array}$ & $\begin{array}{l}\text { Technical } \\
\text { assistance to } \\
\text { olive growing } \\
\text { farmers }\end{array}$ & $\begin{array}{l}\text { Support to the } \\
\text { management of } \\
\text { your olive grove } \\
\text { farm }\end{array}$ & $\begin{array}{l}\text { Trends in current climate, } \\
\text { production and potential } \\
\text { olive fly attack parameters }\end{array}$ \\
\hline \multirow{4}{*}{ 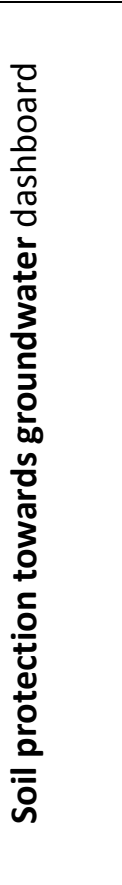 } & E1 & $\begin{array}{l}\text { E1.1 Agriculture } \\
\text { Department of } \\
\text { Regione Campania; } \\
\text { E1.2 Ministry } \\
\text { Environment }\end{array}$ & $\begin{array}{l}\text { Update of } \\
\text { Nitrate } \\
\text { Vulnerable } \\
\text { Zones }\end{array}$ & $\begin{array}{l}\text { Internet GIS } \\
\text { facilities } \\
\text { Intrinsic Soil } \\
\text { Protective } \\
\text { Capacity }\end{array}$ & $\begin{array}{l}\text { Maps (e.g.low protective } \\
\text { soils, hydrogeology, land } \\
\text { use) to evaluate update of } \\
\text { vulnerable zones, }\end{array}$ \\
\hline & E2 & $\begin{array}{l}\text { E2.1Agriculture } \\
\text { Department of } \\
\text { Regione Campania; } \\
\text { E2.2 Ministry } \\
\text { Environment }\end{array}$ & $\begin{array}{l}\text { Update and } \\
\text { ameliorate the } \\
\text { Action Plans for } \\
\text { nitrate and } \\
\text { other pollutants }\end{array}$ & $\begin{array}{l}\text { Interactive } \\
\text { Estimate of Soil } \\
\text { Protection } \\
\text { Capacity }\end{array}$ & $\begin{array}{l}\text { Evaluation of the } \\
\text { interaction climate-soil- } \\
\text { crop in determining } \\
\text { protection towards } \\
\text { groundwater. Support for } \\
\text { guidelines. }\end{array}$ \\
\hline & E3 & $\begin{array}{l}\text { E3.1 Agriculture } \\
\text { Department of } \\
\text { Regione Campania; } \\
\text { E3.2 Farmers and } \\
\text { farmer associations }\end{array}$ & $\begin{array}{l}\text { Criteria for the } \\
\text { derogation } \\
\text { sludge rules }\end{array}$ & $\begin{array}{l}\text { Interactive } \\
\text { Estimate of Soil } \\
\text { Protection } \\
\text { Capacity and } \\
\text { Estimate current } \\
\text { soil water content } \\
\end{array}$ & $\begin{array}{l}\text { Soil water content to be } \\
\text { incorporated into } \\
\text { guidelines }\end{array}$ \\
\hline & E4 & $\begin{array}{l}\text { E4. Farmers and } \\
\text { farmer associations }\end{array}$ & $\begin{array}{l}\text { Support to } \\
\text { farmer } \\
\text { application for } \\
\text { EU subsidies } \\
\text { (Compliance } \\
\text { System) }\end{array}$ & $\begin{array}{l}\text { Interactive } \\
\text { Estimate of Soil } \\
\text { Protection } \\
\text { Capacity }\end{array}$ & $\begin{array}{l}\text { Evaluation of management } \\
\text { units of farm in current } \\
\text { protection towards } \\
\text { groundwater. }\end{array}$ \\
\hline
\end{tabular}

Table SM1 Supplementary material . Details about olive growing and groundwater protection issues, endusers, employed tools and output implemented in SOILCONSWEB-GCI. 